\title{
Fundamental basis of patient-specific caries prevention
}

\author{
Dmitry A. Kunin \\ From EPMA-World Congress 2013 \\ Brussels, Belgium. 20-21 September 2013
}

Clinical introduction of methods for personalized preventive medicine, it is essential to unravel biochemical components and ultastructural features of hard dental tissues. Accordingly, utilizing a variety of techniques and protocols (e.g., electron probe microanalysis, atomicpowered tunnel electron microscopy), the essential structural features of enamel (e.g., "enamel bridges" and "enamel tunnels") have been identified. These studies have also led to our better understanding of some metabolic processes in teeth.

Detection of previously unrecognized structures in enamel and dentin has helped explain the selectivity of chemical elements and their actions in the context of preventive means and the necessity of personalization of carious and not carious teeth diseases prevention.

Our studies suggest that "enamel tunnels" play a major role in exchange processes between the tooth enamel and oral fluid stimulating mineral penetration of the dental enamel by molecular substances and microorganisms (i.e. functioning as a tissue barrier). Therefore, the enamel surface must be kept unexposed and the tooth openings must be treated to prevent its morphochemical alterations. The protective zone is non-cariogenic dental plaque sublimating necessary organic and inorganic components of the oral fluid. It appears difficult to accumulate this "plaque" but it becomes possible with the preventive means. Therefore, it is imperative to improve the professional oral care techniques in order to determine an acceptable level of caries prevention efficiency.

Published: 11 February 2014

Correspondence: kunin36@gmail.com

Voronezh N.N. Burdenko State Medical Academy, Dentistry Department, Voronezh, Russia

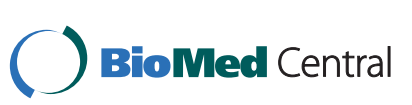

(c) 2014 Kunin; licensee BioMed Central Ltd. This is an Open Access article distributed under the terms of the Creative Commons Attribution License (http://creativecommons.org/licenses/by/2.0), which permits unrestricted use, distribution, and reproduction in any medium, provided the original work is properly cited. The Creative Commons Public Domain Dedication waiver (http:// creativecommons.org/publicdomain/zero/1.0/) applies to the data made available in this article, unless otherwise stated.
doi:10.1186/1878-5085-5-S1-A118

Cite this article as: Kunin: Fundamental basis of patient-specific caries prevention. EPMA Journal 2014 5(Suppl 1):A118.

Submit your next manuscript to BioMed Central and take full advantage of:

- Convenient online submission

- Thorough peer review

- No space constraints or color figure charges

- Immediate publication on acceptance

- Inclusion in PubMed, CAS, Scopus and Google Scholar

- Research which is freely available for redistribution Submit your manuscript at
www.biomedcentral.com/submit C BioMed Central 